\title{
The Relationships Among Writing Self-Efficacy, Writing Goal Orientation, and Writing Achievement
}

\author{
Sathya Chea \\ Royal University of Phnom Penh, Cambodia \\ Lee Shumow \\ Northern Illinois University, DeKalb, Illinois, USA
}

\begin{abstract}
This study examined writing self-efficacy, writing goal orientation, and writing achievement among $(N=244)$ Cambodian university students studying English as a foreign language. Most studies of the relationships among these motivational constructs have been conducted in western contexts, and the findings of those studies might not be generalizable to Asian students. The study first examined whether writing self-efficacy and writing goal orientation were structured similarly by Cambodian students and western students. Factor analyses and Cronbach's alpha provided evidence of the unidimensionality of writing self-efficacy and of a tripartite structure for writing goal orientation. Second, the study investigated the relationships between writing self-efficacy, writing goal orientation, and writing achievement. Pearson Product-Moment Correlations showed that writing self-efficacy was related to writing mastery and performance-avoidance goal orientations. All writing goal orientation measures were related positively. Both writing self-efficacy and writing mastery goal orientation were shown to have positive correlations with writing achievement.
\end{abstract}

Self-efficacy is among the most notable motivational constructs educational psychologists have been examining (Lane, Lane, \& Kyprianou, 2004; Pajares \& Valiante, 1999; Shell, Colvin, \& Bruning, 1995). Recently, researchers have investigated how self-efficacy is related to goal orientation, another notable motivational construct (Liem, Lau, \& Nie, 2007; Phan, 2009, 2010). Most research on these constructs has been conducted in western and / or developed countries. This study was conducted in a developing nation, Cambodia. Participants were university students studying English as a foreign language (EFL); few studies regarding the concepts of self-efficacy and goal orientation have been conducted in this context.

This study had two main purposes. The first was to investigate whether writing self-efficacy and writing goal orientation were structured similarly by Cambodian EFL students and the more widely-studied western students. The second purpose was to test the relationship among writing self-efficacy, writing goal orientation, and writing achievement to ascertain whether the relationships found in western contexts are also observed among Cambodian students. 


\section{Self-Efficacy}

Self-efficacy is defined as "beliefs in one's capabilities to organize and execute the courses of action required to manage prospective situations" (Bandura, 1997, p. 2). The current study examined self-efficacy in the specific subject of writing; thus, writing self-efficacy is defined as students' ability to perform in writing tasks, and specifically in the context of this study, students' ability to write paragraphs in English. Bandura posited that self-efficacy affects a person's behavior, which further causes him / her to achieve a particular outcome. Self-efficacy affects behavior such that a person with high self-efficacy tends to expend considerable effort when performing tasks and perseveres despite difficulty, thereby achieving good results. On the other hand, according to Bandura (1997), a person with low self-efficacy tends to expend less effort and give up easily when facing difficulty, and consequently achieves less. Self-efficacy also influences the activities an individual chooses to do. A person who believes in his / her ability will choose to do challenging tasks, while a person who doubts his / her ability will avoid situations which seem to exceed his / her ability.

Bandura (1977) also stressed that any study of efficacy should take into account three main dimensions: magnitude, generality, and strength. According to Bandura, magnitude means the difficulty and complexity of the task, generality refers to whether the task is associated with a general or specific sense of efficacy, and strength simply means how weak or strong a person's efficacy is. In his subsequent work, Bandura (1986) posited that students' self-efficacy explained the effect of other factors of academic achievement (i.e., skill or past performance) on later performance / achievement. The current study follows Bandura's advice on the measurement of self-efficacy construct. Therefore, students' writing efficacy was measured using an efficacy measure (which can be seen in Appendix A) that specifically deals with students' ability to write English paragraphs, rather than a general self-efficacy measure.

\section{Goal Orientation}

Goal orientation also has been used to frame studies of academic motivation and achievement. Pintrich (2003) described goal orientation as the reason behind students' achievement behavior. Initially, researchers distinguished between learning and performance-goal orientation (Dweck \& Leggett, 1988). Nicholls (1984) used the term task-involved in place of learning and ego-involved in place of performance, whereas Ames and Archer (1988) used the terms mastery and performance goals. While there are minor differences in these terms, there is enough similarity among them that they can be conceptualized as the same characteristics (Schunk, Pintrich, \& Meece, 2008). Recently, researchers have further divided performancegoal orientation into performance-approach and performance-avoidance subcategories and have examined the individual influence of each in various studies. Although some researchers also have posited a mastery-avoidance orientation, that construct has not been widely accepted.

In this study, the trichotomous structure of goal orientation (which consists of mastery, performance-approach, and performance-avoidance goals) is used. Students who are high in mastery goal orientation seek to gain understanding and competence in their learning and thus are willing to undertake challenging tasks in order to learn more (Dweck \& Leggett, 1988). Students who are high in performance-approach goal orientation seek to show off their competence or ability, and hence focus on gaining good grades and outperforming their classmates. Students with a performance-approach orientation are more likely to avoid challenging tasks than those with mastery goal orientation, because they do not want to risk coming behind in competitions. As a result, performance-approach-oriented students have lower persistence in the face of difficulty (Dweck \& Leggett, 1988). Students high in performance-avoidance goal orientation seek to avoid appearing incompetent in front of others 
(Elliot, 1999), avoid tasks which they perceive as challenging, and tend to lose confidence and give up when confronting challenging tasks.

Both mastery- and performance-approach-oriented students are expected to study hard and gain similar achievement in tasks that do not require much effort; however, students with a mastery goal orientation might perform better than those with performance-approach goal orientation in challenging and complicated tasks such as writing, which is the focus of this study. Students who are high in performance-avoidance goal orientation are not expected to perform well in a challenging subject such as writing.

\section{Self-Efficacy, Goal Orientation, and Achievement}

Self-efficacy and academic achievement. Bandura (2006) argued that self-efficacy measures should be specific to the subject area studied. In one study, Choi (2005) found that only specific self-efficacy (but not general or academic self-efficacy) predicted the academic achievement of college students in the United States. Other researchers have studied the effect of self-efficacy in specific subject areas such as mathematics at different academic levels. For example, Meece, Wigfield, and Eccles (1990) found that seventh and ninth grade students' general mathematics self-efficacy significantly predicted their mathematics achievement. Studying a similar sample using a task-specific self-efficacy measure, Pajares and Graham (1999) found the same result. The significant influence of mathematics self-efficacy on mathematics achievement is also reported in studies at the university level (Cooper \& Robinson, 1991; Hackett \& Betz, 1989; Pajares \& Miller, 1995).

Writing self-efficacy has been reported as a significant predictor of writing achievement of students at different academic levels. Shell, Murphy, and Bruning (1989) constructed a writing self-efficacy scale which measured students' skills in different writing tasks (e g., writing a letter and writing an essay) and students' skills in writing components (e.g., spelling and parts of speech). They found that writing self-efficacy significantly predicted writing achievement as measured by students' holistically scored essays. They then adapted the writing self-efficacy scale to study the fourth, seventh, and tenth graders and found that students' writing selfefficacy predicted their reading and writing achievement operationalized as mechanical skill and essay writing (Shell et al., 1995). Similar findings have been reported in other studies of writing self-efficacy and writing achievement (McCarthy, Meier, \& Rinderer, 1985; Pajares \& Johnson, 1996; Pajares \& Valiante, 1997, 1999). Given the positive impact that writing selfefficacy has on writing achievement stated in the literature, this study used a self-efficacy scale that specifically measures students' confidence in their ability to write English paragraphs (see items in Appendix A).

Self-efficacy and goal orientation. Research has produced consistent results regarding the positive relationship between self-efficacy and mastery goal orientation (Elliot \& Church, 1997; Liem et al., 2007; Phan, 2010). However, there have been inconsistent findings regarding the relationship between self-efficacy and performance-approach goal orientation. Some studies showed that self-efficacy had a significant positive relationship with performance-approach goal orientation (e.g., Greene \& Miller, 1996), while some others reported a nonsignificant relationship between the two variables (Elliot \& Church, 1997; Liem et al., 2007; Phan, 2010; Skaalvik, 1997; Wolters, 2004). Similarly, studies on the relationship of self-efficacy with performance-avoidance goal orientation have found either a null (Hsieh, Sullivan, \& Guerra, 2007; Phan, 2010) or a negative relationship between self-efficacy and performance-avoidance goal orientation (Liem et al., 2007). 
Goal orientation and academic achievement. Although Dweck and Leggett (1988) posited that goal orientation led students to choose adaptive or maladaptive learning behaviors, thus influencing their academic achievement, subsequent research has produced inconclusive results on the relationship between goal orientation and academic achievement. Some studies showed mastery goal orientation has a positive relationship with academic achievement (Sins, van Joolingen, Savelsbergh, \& van Hout-Wolters, 2008), while others show a null relationship (Liem et al., 2007; Phan, 2010). Similarly, studies on the relationship between performanceapproach goal orientation and achievement reported either a positive relationship (Church, Elliot, \& Gable, 2001; Senko \& Miles, 2008; Wolters, 2004) or a null relation (Dupeyrat \& Mariné, 2005; Phan, 2010) between these variables. Other studies have found either a negative association (Simons, Dewitte, \& Lens, 2004) or a null relation (Phan, 2010; Senko \& Miles, 2008) between performance-avoidance goal orientation and achievement.

Although so far there has been considerable research on self-efficacy and its relation to goal orientation and academic achievement, as revealed in the review of the literature, most of the studies were conducted using measures of general self-efficacy and goal orientation. A few studies focused on measures of self-efficacy in specific subjects like writing. Among those studies, none were found that were conducted at an Asian EFL college. Therefore, this current study aimed to address this gap in literature by examining the relation of writing self-efficacy and writing goal orientation with writing achievement in a non-western context. Two research questions were addressed in this study:

1. How are writing self-efficacy and writing goal orientation structured by Cambodian EFL learners?

2. How are writing self-efficacy, writing goal orientation, and writing achievement related to each other?

\section{Context}

\section{Method}

The study was conducted in the capital of Cambodia at a prestigious semi-private university which provides a four-year bachelor's program in English. Admission to this program is based on high school examination grades and at least intermediate performance on an English proficiency examination. The students who pass the entrance exam must have had quite solid background in English language learning.

The university provides three learning shifts, each of which consists of two 90-minute sessions: morning (7:30 a.m.-11:00 a.m.), afternoon (2:00 p.m.-5:00 p.m., or evening (5:30 p.m.-8:30 p.m.). Students study one shift a day, five days a week, throughout each semester. Students choose to study during whichever shift they want. Most of the students who take classes in the evening shift are also engaged in either part-time or full-time employment in various fields.

The students take four required course strands with no electives: Core English, Literature Studies, Global Studies, and Writing Skills. The medium of instruction and communication is supposed to be English in all courses. This present study focuses on Year 2 students in Writing Skills classes, in which students are taught different types of writing in both paragraph and essay formats.

\section{Participants}

Approximately 600 Year 2 students are enrolled in the bachelor's program of English at the university. Nine classes were randomly selected to participate. Of the 281 students in those 
classes, 87\%, or 244 ( $n=121$ males, $n=123$ females), returned the questionnaires they were given.

\section{Questionnaire}

The questionnaire (see Appendix A) administered to students consisted of four sections. The first elicited students' self-efficacy with seven items. The second was about students' writing goal orientation and contained 14 items. The third, which contained 12 items, asked students about their learning strategies. The last section, with only two items, asked for students' background information-students' gender and learning shift (morning, afternoon, or evening) - to be used in the study. The questionnaire was administered, with permission from the department head and class lecturers, to students at the beginning of their class. It took them about 15 minutes to complete the questionnaire.

\section{Measures}

It is essential to establish measurement accuracy before testing relationships among the key variables. It cannot be assumed that measures developed in western countries will adequately measure motivation in other societies. Below are measures of key variables in this study.

Writing achievement. Students' paragraph scores, ranging from 0 to 50 on their writing final exam, were used to reflect writing achievement. Students were given two or three general topics to write a paragraph about for the exam. Lecturers scored students' paragraphs, following six features of writing skills focused on in the curriculum (i.e., grammar, word use, coherence and cohesion, punctuation, writing planning, and introduction and conclusion writing) and a holistic approach, which "assumes that in a writing assessment students should write, and that error counts alone cannot accurately reflect competency levels" (Myers, 1980, p. 1).

Lecturers used three different versions of the exam, resulting in different versions of paragraphs. Therefore, inter-rater reliability was established to ensure the reliability of the scores obtained as measures of participants' writing achievement. Five to ten copies of participants' paragraphs scored by each teacher in each shift were also scored by another rater. Scores from the rater were compared with the scores from the teachers and an inter-rater reliability index was calculated. Inter-rater reliability was .71.

Writing self-efficacy. This study operationalized students' writing achievement as paragraphwriting achievement. In accordance with Bandura's (2006) suggestions, the writing self-efficacy scales reflected students' paragraph-writing self-efficacy and utilized an 11-point response scale, ranging from 0 ( Totally Disagree) to 100 ( Totally Agree) with a 10-unit interval. The writing self-efficacy scale consisted of seven items (see Appendix A), which were based on PratSala and Redford (2010) because the items matched well with the way writing skills were taught at the university in this study.

Writing goal orientation. Scales developed by Kaplan, Lichtinger, and Gorodetsky (2009) were used to measure writing goal orientation. Those writing mastery and performance-approach goal orientation scales each contained five items with average alpha $(\alpha)$ values of .89 and .90, respectively. The writing performance-avoidance goal orientation scale contained four items with an $\alpha$ value of .79. Cronbach's $\alpha$ reflects the interrelation among items supposed to measure the same construct, so a high alpha value indicates high internal consistency among the items of the measure. According to Santos (1999), an acceptable alpha value should be at least .70, although there may be some exceptions. Students used a seven-point Likert response 
scale ranging from 1 (Totally Disagree) to 7 (Totally Agree) to respond to each item (see Appendix A).

\section{Results \\ Structure of Writing Self-Efficacy and Goal Orientation Measures in the Cambodian EFL Context}

Research Question 1 asked whether the measures of writing self-efficacy and writing goal orientation would be structured by Cambodian EFL students in the same way as they were by the western students for whom the measures were developed. To determine this, the principalcomponent analysis technique (Field, 2009; Kline, 1994) was used, as this technique allows researchers to examine the unidimensionality of a construct through different measurement items.

Structure of writing self-efficacy. To assess unidimensionality of the writing self-efficacy construct, a principal-component analysis with varimax rotation was conducted on the data. Only items with loadings of 0.40 , a commonly used cutoff, were retained (Kline, 1994). Results are displayed in Table B1 in Appendix B.

In order to be retained, a scale should have an eigenvalue greater than one and the variance explained by the factor analysis should be greater than $50 \%$. All seven items from the original writing self-efficacy scale produced one component with eigenvalue $=4.7$, which accounted for a variance in the items of $66.8 \%$.

Cronbach's $\alpha$ is the most common index researchers use to determine the internal reliability of a scale (Field, 2009). A high value of Cronbach's $\alpha$ suggests high internal reliability of a scale. The data collected in this study yielded a Cronbach's $\alpha$ of .92, which was commensurate with the reliability found in western samples.

In this study, the scores from the self-efficacy measures yielded $M=66, S D=11.45$. Taken together, the results of the factor analysis and Cronbach's $\alpha$ suggest that the structure of selfefficacy by the Cambodian EFL university students is similar to that found in western samples.

Writing goal orientation structure. The same procedures were followed with the writing goal orientation measure as with the writing self-efficacy measure. However, while items from the writing self-efficacy measure were expected to form one scale, items from writing goal orientation measures were expected to form three subscales because of the tripartite nature of the expected structure.

A principal-component analysis was conducted (using varimax rotation) on the writing goal orientation measure. Table B2 in Appendix B displays factor loadings for the goal orientation items. Fourteen items of the writing goal orientation measures yielded three components with eigenvalues $=4.53,2.72$, and 1.53 , respectively, which accounted for $62.76 \%$ of the variance in the items. Two of the total of 14 items (Items 3 and 5 of the measure of the writing performance approach goal orientation [Items 15 and 17, respectively, in the questionnaire]), were discarded because they loaded on two different components. The final 12 items were categorized into three components: mastery (five items), performance approach (three items), and performance avoidance (four items).

The scores from the final writing goal orientation measures yielded $M=6, S D=.68$, Cronbach's $\alpha=.81$ for mastery goal orientation; $M=4.26, S D=1.23$, Cronbach's $\alpha=.85$ for performance-approach goal orientation; and $M=4.44, S D=1.28$, Cronbach's $\alpha=.79$ for 
performance-avoidance goal orientation. Thus, Research Question 1 can be answered in the affirmative for both constructs. That is, measures of writing self-efficacy and writing goalorientation were structured by Cambodian EFL students as they were structured by western students.

\section{Relationships of Writing Self-Efficacy, Goal Orientation, and Achievement}

Research Question 2 addressed the relationship between writing self-efficacy, writing goal orientation, and writing achievement. To answer this question, Pearson Product-Moment Correlation analyses were used.

The results of these analyses are shown in Table B3 in Appendix B. As expected, writing selfefficacy significantly correlated in a positive manner with writing mastery goal orientation, $r(242)=.40, p<.001$, and with writing achievement, $r(242)=.15, p<.05$. Unexpectedly, writing self-efficacy also correlated positively with writing avoidance goal orientation, $r(242)=$ $.17, p<.01$. Writing self-efficacy did not have a significant correlation with writing performance-approach goal orientation, $r(242)=.04, p>.05$.

Writing mastery goal orientation had a positive correlation with writing performance-approach goal orientation, $r(242)=.14, p<.05$, and, as expected, with writing achievement, $r(242)=$ $.11, p<.05$.

Writing self-efficacy, as expected, was significantly and positively correlated with writing achievement, $r(242)=.15, p<.05$, as was writing mastery goal orientation, $r(242)=.11, p<$ .05. The two writing performance goal orientations did not have a significant relationship with writing achievement.

\section{Discussion}

\section{Reliability and Validity of the Scores From Measures}

Research Question 1 examined the structures of the constructs of writing self-efficacy and writing goal orientation in the Cambodian context. Each of the measures used in this study was found to have high reliability, as the scores obtained from the measures produced sufficient to high Cronbach's alpha values. Principal-component factor analyses conducted on the measures in this study suggested unidimensionality in each construct, which provides some evidence for the validity of the scores from the measures. These findings regarding the reliability and validity of the scores in this study were important because there have not been any tests conducted to examine these constructs in Cambodia; thus, these measures, presented in English, can be used in future research in Cambodia. Future studies can also examine whether similar structures will be found if the items are translated into Khmer, the Cambodian language.

\section{Relationship Between Writing Self-Efficacy and the Other Variables}

Research Question 2 in this study pertained to how writing self-efficacy related to writing goal orientation. Results reveal that, as expected, writing self-efficacy was related to writing mastery goal orientation and to writing achievement. These findings suggest that students who have high self-efficacy in English writing tend to focus more on learning for improvement and understanding when they are learning writing skills. These findings are consistent with those from a number of other studies including Elliot and Church (1997), Liem et al. (2007), and Phan (2010), that also showed a relationship between self-efficacy and mastery goal orientation. 
Furthermore, writing self-efficacy was not significantly related to writing performance-approach orientation. Research has produced varied results ranging from positive to null relationships between writing self-efficacy and writing performance-approach goal orientation. The current study examined the relationship between the two constructs in a specific subject matter of writing skills and a new setting in which the population is learners of EFL. The population of this study typically finds writing in English a difficult subject because, to write, they have to articulate their ideas in a second language in addition to deciding what ideas to incorporate in their writing. They need to use correct grammar and vocabulary in a second language, which naturally adds burdens to their effort to write. In such a difficult subject, students with high writing performance-approach goal orientation may lose confidence and give up as predicted by Dweck and Leggett (1988).

The only unexpected result was the observed positive relationship between writing self-efficacy and writing performance-avoidance orientation. This result is inconsistent with previous studies (Liem et al., 2007), which might suggest that while the population in this study possesses belief in their own ability to write well, they also feel fear of embarrassment from failing the subject.

Research Question 2 also addressed the relationship between writing self-efficacy, writing goal orientation, and writing achievement. Results from this study indicate a positive relationship between writing self-efficacy and writing achievement. This result is in agreement with those obtained in myriad studies on the relationship between writing self-efficacy and achievement in general academic subjects as well as in writing as a subject (Dupeyrat \& Mariné, 2005; Liem et al., 2007; Pajares \& Johnson, 1996; Pajares \& Valiante, 1997, 1999; Phan, 2009, 2010) and extends evidence supporting Bandura's theory to a new context.

Results further show that writing mastery goal orientation had a positive correlation with writing achievement, suggesting that students who focus on learning writing for improvement and understanding tend to fare well in their academic writing tasks. This finding is consistent with many studies in western countries conducted in various fields of study (Hsieh et al., 2007; Sins et al., 2008).

Another expected result was the null relationship between writing performance-approach goal orientation and writing achievement. Learning in order to win in competitions might be an adaptive behavior and might lead to success in some academic areas (Church et al., 2001; Senko \& Miles, 2008; Wolters, 2004). Nonetheless, in face of difficulty, such as the difficult subject of writing, performance-approach oriented students often will give up easily (Dweck \& Leggett, 1988), and thus they will not succeed academically.

Writing performance-avoidance goal orientation was also found to have no significant correlation with writing achievement, a result which was not anticipated but which is consistent with two previous studies (Phan, 2010; Senko \& Miles, 2008). Students who are high in writing performance-avoidance goal orientation set out to do writing tasks for the purpose of avoiding looking unwise in front of others and often try to avoid challenging tasks because they will not be able to do well in such tasks.

\section{Limitations}

One of the main limitations in this study is the reliability of the writing scores. In this study, writing scores were obtained from different lecturers, and students wrote on different topics. Further studies on the relationship between writing self-efficacy and writing achievement should employ more standardized scores to ensure enhanced reliability of the scores to reflect students' writing achievement. 
Another limitation is that this study examined students' writing achievement in only one Cambodian English language teaching (ELT) institute. Therefore, the findings from the study might not be generalizable to college students at other ELT institutes in Cambodia or in Asia as a whole. For a broader generalizability of this topic, further studies that cover a wider population are needed.

\section{Conclusion and Implications}

Self-efficacy and goal orientation were conceptualized by scholars to have an influence on academic achievement. Although this study was conducted in a setting in which there had been no previous research on this topic, the structure of the constructs was confirmed. Further, this study found a positive correlation among writing self-efficacy, writing mastery goal orientation, and writing achievement. These are positive results, as they contribute to the existing literature by incorporating goal orientation into the examination of the relationship between self-efficacy and academic achievement in the specific subject area of writing within a new context.

One implication of this study is that EFL teachers might promote higher writing achievement by fostering students' writing self-efficacy and writing mastery goal orientation. Teachers can create an environment that is conducive to promoting students' writing self-efficacy while also orienting them toward mastery in writing. For example, EFL teachers can assign writing tasks that are challenging enough to engage students and to allow them to succeed with hard work. Writing self-efficacy develops through having successful experiences, seeing the success of peers, persuasion that success is possible, and feeling positive, not anxious (Bandura, 1977, 1997).

\section{Author Note}

Sathya Chea, Department of English, Institute of Foreign Languages, Royal University of Phnom Penh, Phnom Penh, Cambodia; Lee Shumow, Department of Leadership, Educational Psychology, and Foundations, Northern Illinois University, DeKalb, Illinois, USA.

This study was based on a Master's Thesis, "The Relationships Among Writing Self-Efficacy, Writing Goal Orientation, Learning Strategies, and Writing Achievement."

Correspondence concerning this article should be addressed to Sathya Chea, Department of English, Institute of Foreign Languages, Royal University of Phnom Penh, Russian Federation Boulevard, Phnom Penh, Cambodia. E-mail: sathyachea@gmail.com 


\section{References}

Ames, C., \& Archer, J. (1988). Achievement goals in the classroom: Students' learning strategies and motivation processes. Journal of Educational Psychology, 80(3) 260-267. http://dx.doi.org/10.1037/0022-0663.80.3.260

Bandura, A. (1977). Self-efficacy: Toward a unifying theory of behavioral change. Psychological Review, 84(2), 191-215. http://dx.doi.org/10.1037/0033-295X.84.2.191

Bandura, A. (1986). Social foundations of thought and action: A social cognitive theory. Englewood Cliffs, NJ: Prentice Hall.

Bandura, A. (1997). Self-efficacy: The exercise of control. New York, NY: Freeman.

Bandura, A. (2006). Guide for constructing self-efficacy scales. In F. Pajares \& T. Urdan (Eds.). Self-efficacy beliefs of adolescents, (Vol. 5, pp. 307-337). Greenwich, CT: Information Age.

Choi, N. (2005). Self-efficacy and self-concept as predictors of college students' academic performance. Psychology in the Schools, 42(2), 197-205. http://dx.doi.org/10.1002/pits.20048

Church, M. A., Elliot, A. J., \& Gable, S. L. (2001). Perceived classroom environment, achievement goals, and achievement outcomes. Journal of Educational Psychology, 93(1), 43-54. http://dx.doi.org/10.1037/0022-0663.93.1.43

Cooper, S. E., \& Robinson, D. A. G. (1991). The relationship of mathematics self-efficacy beliefs to mathematics anxiety and performance. Measurement and Evaluation in Counseling and Development, 24(1), 4-11.

Dupeyrat, C., \& Mariné, C. (2005). Implicit theories of intelligence, goal orientation, cognitive engagement, and achievement. Contemporary Educational Psychology, 30(1), 43-59. http://dx.doi.org/10.1016/j.cedpsych.2004.01.007

Dweck, C. S., \& Leggett, E. L. (1988). A social-cognitive approach to motivation and personality. Psychological Review, 95(2), 256-273. http://dx.doi.org/10.1037/0033295X.95.2.256

Elliot, A. J. (1999). Approach and avoidance motivation and achievement goal. Educational Psychologist, 34(3), 169-189. http://dx.doi.org/10.1207/s15326985ep3403_3

Elliot, A. J., \& Church, M. A. (1997). A hierarchical model of approach and avoidance achievement motivation. Journal of Personality and Social Psychology, 72(1), 218-232. http://dx.doi.org/10.1037/0022-3514.72.1.218

Field, A. (2009). Discovering statistics using SPSS (3rd Ed.). London, England: Sage.

Greene, B. A., \& Miller, R. B. (1996). Influences on achievement: Goals, perceived ability, and cognitive engagement. Contemporary Educational Psychology, 21(2), 181-192. http://dx.doi.org/10.1006/ceps.1996.0015

Hackett, G., \& Betz, N. E. (1989). An exploration of the mathematics self-efficacy/mathematics performance correspondence. Journal for Research in Mathematics Education, 20(3) 261-273. http://dx.doi.org/10.2307/749515

Hsieh, P., Sullivan, J. R., \& Guerra, N. S. (2007). A closer look at college students: Self-efficacy and goal orientation. Journal of Advanced Academics, 18(3), 454-476.

Kaplan, A., Lichtinger, E., \& Gorodetsky, M. (2009). Achievement goal orientations and selfregulation in writing: An integrative perspective. Journal of Educational Psychology, 101(1), 51-69. http://dx.doi.org/10.1037/a0013200

Kline, P. (1994). An easy guide to factor analysis. London, England: Routledge.

Lane, J., Lane, A., \& Kyprianou, A. (2004). Self-efficacy, self-esteem and their impact on academic performance. Social Behavior and Personality, 32(3), 247-256.

http://dx.doi.org/10.2224/sbp.2004.32.3.247 
Liem, A. D., Lau, S., \& Nie, Y. (2007). The role of self-efficacy, task value, and achievement goals in predicting learning strategies, task disengagement, peer relationship, and achievement outcome. Contemporary Educational Psychology, 33(4), 486-512. http://dx.doi.org/10.1016/j.cedpsych.2007.08.001

McCarthy, P., Meier, S., \& Rinderer, R. (1985). Self-efficacy and writing: A different view of selfevaluation. College Composition and Communication, 36(4), 465-471. http://dx.doi.org/10.2307/357865

Meece, J. L., Wigfield, A., \& Eccles, J. S. (1990). Predictors of math anxiety and its influence on young adolescents' course enrollment and performance in mathematics. Journal of Educational Psychology, 82(1), 60-70. http://dx.doi.org/10.1037/0022-0663.82.1.60

Myers, M. (1980). A procedure for writing assessment and holistic scoring. Urbana, IL: ERIC Clearinghouse on Reading and Communication Skills, National Institute of Education, and National Council of Teachers of English. Available at http://files.eric.ed.gov/fulltext/ED193676.pdf

Nicholls, J. G. (1984). Achievement motivation: Conceptions of ability, subjective experience, task choice, and performance. Psychological Review, 91(3), 328-346. http://dx.doi.org/10.1037/0033-295X.91.3.328

Pajares, F., \& Graham, L. (1999). Self-efficacy, motivation constructs, and mathematics performance of entering middle school students. Contemporary Educational Psychology, 24(2), 124-139. http://dx.doi.org/10.1006/ceps.1998.0991

Pajares, F., \& Johnson, M. J. (1996). Self-efficacy beliefs and the writing performance of entering high school students. Psychology in the Schools, 33(2), 163-175. http://dx.doi.org/10.1002/(SICl)1520-6807(199604)33:2<163::AID-PITS10>3.0.CO;2-C

Pajares, F., \& Miller, M. D. (1995). Mathematics self-efficacy and mathematics outcomes: The need for specificity of assessment. Journal of Counseling Psychology, 42(2), 190-198. http://dx.doi.org/10.1037/0022-0167.42.2.190

Pajares, F., \& Valiante, G. (1997). Influence of self-efficacy on elementary students' writing. The Journal of Educational Research, 90(6), 353-360. http://dx.doi.org/10.1080/00220671.1997.10544593

Pajares, F., \& Valiante, G. (1999). Grade level and gender differences in the writing self-beliefs of middle school students. Contemporary Educational Psychology, 24(4), 390-405. http://dx.doi.org/10.1006/ceps.1998.0995

Phan, H. P. (2009). Relations between goals, self-efficacy, critical thinking and deep processing strategies: A path analysis. Educational Psychology, 29(7), 777-799. http://dx.doi.org/10.1080/01443410903289423

Phan, H. P. (2010). Students' academic performance and various cognitive processes of learning: An integrative framework and empirical analysis. Educational Psychology, 30(3), 297-322. http://dx.doi.org/10.1080/01443410903573297

Pintrich, P. R. (2003). A motivational science perspective on the role of student motivation in learning and teaching contexts. Journal of Educational Psychology, 95(4), 667-686. http://dx.doi.org/10.1037/0022-0663.95.4.667

Prat-Sala, M., \& Redford, P. (2010). The interplay between motivation, self-efficacy, and approaches to studying. British Journal of Educational Psychology, 80(2), 283-305. http://dx.doi.org/10.1348/000709909X480563

Santos, J. R. (1999). Cronbach's alpha: A tool for assessing the reliability of scales. Journal of Extension, 37(2). Available at http://www.joe.org/joe/1999april/tt3.html

Schunk, D. H., Pintrich, P. R., \& Meece, J. L. (2008). Motivation in education: Theory, research, and applications. Upper Saddle River, NJ: Pearson Prentice Hall.

Senko, C., \& Miles, K. M. (2008). Pursuing their own learning agenda: How mastery-oriented students jeopardize their class performance. Contemporary Educational Psychology, 33(4), 561-583. http://dx.doi.org/10.1016/j.cedpsych.2007.12.001 
Shell, D. F., Colvin, C., \& Bruning, R. H. (1995). Self-efficacy, attribution, and outcome expectancy mechanisms in reading and writing achievement: Grade-level and achievement-level differences. Journal of Educational Psychology, 87(3), 386-398. http://dx.doi.org/10.1037/0022-0663.87.3.386

Shell, D. F., Murphy, C. C., \& Bruning, R. H. (1989). Self-efficacy and outcome expectancy mechanisms in reading and writing achievement. Journal of Educational Psychology, 81(1), 91-100. http://dx.doi.org/10.1037/0022-0663.81.1.91

Simons, J., Dewitte, S., \& Lens, W. (2004). The role of different types of instrumentality in motivation, study strategies, and performance: Know why you learn, so you'll know what you learn. British Journal of Educational Psychology, 74(3), 343-360. http://dx.doi.org/10.1348/0007099041552314

Sins, P. H. M., van Joolingen, W. R., Savelsbergh, E. R., \& van Hout-Wolters, B. (2008). Motivation and performance within a collaborative computer-based modeling task: Relations between students' achievement goal orientation, self-efficacy, cognitive processing, and achievement. Contemporary Educational Psychology, 33(1), 58-77. http://dx.doi.org/10.1016/j.cedpsych.2006.12.004

Skaalvik, E. M. (1997). Self-enhancing and self-defeating ego orientations: Relations with task and avoidance orientation, achievement, self-perceptions, and anxiety. Journal of Educational Psychology, 89(1), 71-81. http://dx.doi.org/10.1037/0022-0663.89.1.71

Wolters, C. A. (2004). Advancing achievement goal theory: Using goal structures and goals orientations to predict students' motivation, cognition, and achievement. Journal of Educational Psychology, 96(2), 236-250. http://dx.doi.org/10.1037/0022-0663.96.2.236 


\section{Appendix A \\ Questionnaire}

(Based on Prat-Sala \& Redford, 2010; Kaplan, Lichtinger, \& Gorodetsky, 2009)

Instruction: Please circle the options which best describe you and your beliefs and behaviors in learning.

\section{Writing belief}

To what extent do you agree with the following statements?

I am confident that

1. I can write a grammatically correct paragraph.

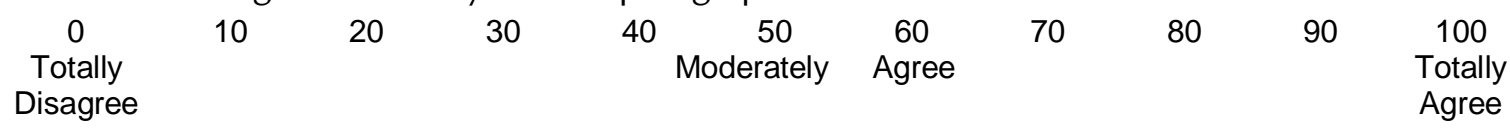

2. I can use correct punctuation marks-for example, commas, full stops, semi-colons, etc.- in a paragraph.

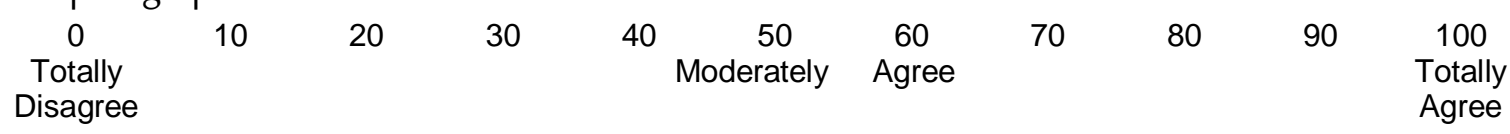

3. I can plan my paragraph well.

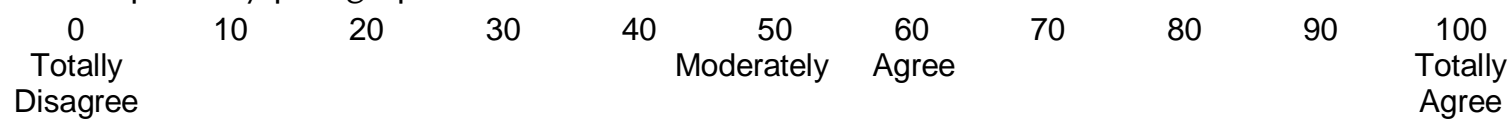

4. I can write a good introduction which informs the reader of my intention for a paragraph.

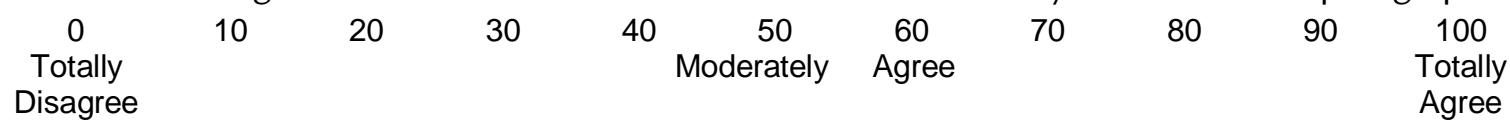

5. I can put ideas together in a paragraph in such a way that they are clear to the reader.

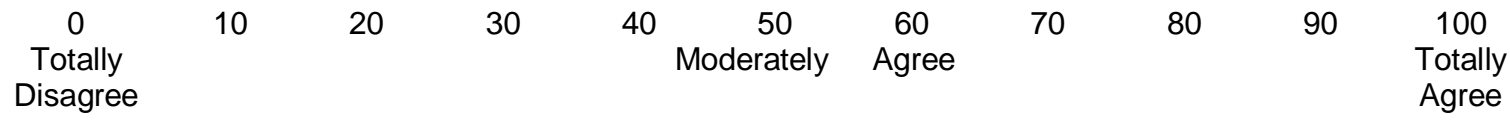

6. I can link sentences together to make a well-organized paragraph.

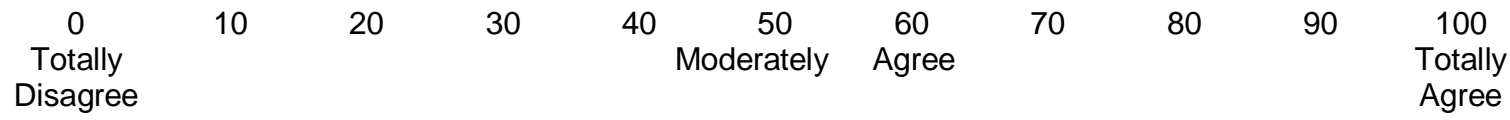

7. I can make a good conclusion to inform the reader of the ending of my paragraph.

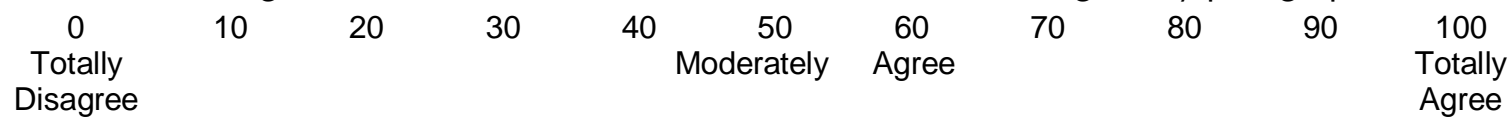




\section{Writing goal}

To what extent do you agree with the following statements?

When I do a writing assignment, writing in-class work, or writing homework,

8. it's important to me that I learn as much as I can.

$\begin{array}{ccccccc}1 & 2 & 3 & 5 & 6 & 7 \\ \text { Totally } & & & & & \text { Totally } \\ \text { Disagree } & & & & \text { Agree }\end{array}$

9. it's important to me that I improve my skills and knowledge.

$\begin{array}{ccccccc}1 & 2 & 3 & 4 & 5 & 6 & 7 \\ \text { Totally } & & & & & \text { Totally } \\ \text { Disagree } & & & & \text { Agree }\end{array}$

10. one of my goals is to learn as much as I can.

$\begin{array}{ccccccc}1 & 2 & 3 & 5 & 6 & 7 \\ \text { Totally } & & & & & \text { Totally } \\ \text { Disagree } & & & & \text { Agree }\end{array}$

11. it's important for me to really understand what there is to learn.

$\begin{array}{ccccccc}1 & 2 & 3 & 4 & 5 & 6 & 7 \\ \text { Totally } & & & & & \text { Totally } \\ \text { Disagree } & & & & \text { Agree }\end{array}$

12. one of my goals is to develop deep understanding of what I am learning.

$\begin{array}{ccccccc}1 & 2 & 3 & 4 & 5 & 6 & 7 \\ \text { Totally } & & & & & \text { Totally } \\ \text { Disagree } & & & & \text { Agree }\end{array}$

13. it's important for me to look smart in comparison to the other students in my class.

$\begin{array}{ccccccc}1 & 2 & 3 & 4 & 5 & 6 & 7 \\ \text { Totally } & & & & & \text { Totally } \\ \text { Disagree } & & & & \text { Agree }\end{array}$

14. one of my goals is to look smart compared to others in my class.

$\begin{array}{ccccccc}1 & 2 & 3 & 5 & 6 & 7 \\ \text { Totally } & & & & & \text { Totally } \\ \text { Disagree } & & & & & \text { Agree }\end{array}$

15. one of my goals is to show others that those writing tasks were easy for me.

$\begin{array}{ccccccc}1 & 2 & 3 & 4 & 5 & 6 & 7 \\ \text { Totally } & & & & & \text { Totally } \\ \text { Disagree } & & & & \text { Agree }\end{array}$

16. it's important to me that other students in my class think I am good at it.

$\begin{array}{ccccccc}1 & 2 & 3 & 5 & 5 & 6 & 7 \\ \text { Totally } & & & & & \text { Totally } \\ \text { Disagree } & & & & \text { Agree }\end{array}$

17. one of my goals is to show others that I'm good at this work.

$\begin{array}{ccccccc}1 & 2 & 3 & 5 & 6 & 7 \\ \text { Totally } & & & & & \text { Totally } \\ \text { Disagree } & & & & & \text { Agree }\end{array}$


18. it's important to me that others don't see me as a stupid student.

$\begin{array}{ccccccc}1 & 2 & 3 & 4 & 5 & 6 & 7 \\ \text { Totally } & & & & & \text { Totally } \\ \text { Disagree } & & & & & \text { Agree }\end{array}$

19. it's important to me that my teacher doesn't think that I know less than others in class.

$\begin{array}{ccccccc}1 & 2 & 3 & 5 & 6 & 7 \\ \text { Totally } & & & & & \text { Totally } \\ \text { Disagree } & & & & \text { Agree }\end{array}$

20. one of my goals is to keep others from thinking l'm not smart.

$\begin{array}{ccccccc}1 & 2 & 3 & 4 & 5 & 6 & 7 \\ \text { Totally } & & & & & \text { Totally } \\ \text { Disagree } & & & & \text { Agree }\end{array}$

21. one of my goals is to avoid looking like I have trouble doing the work.

$\begin{array}{ccccccc}1 & 3 & 3 & 5 & 6 & 7 \\ \text { Totally } & & & & & \text { Totally } \\ \text { Disagree } & & & & & \text { Agree }\end{array}$

\section{Learning strategies}

To what extent do you agree with the following statements about your learning strategies in general, not just in writing?

22. I study a course material by repeating the material over and over different times.

$\begin{array}{ccccccc}1 & 2 & 3 & 4 & 5 & 6 & 7 \\ \begin{array}{c}\text { Totally } \\ \text { Disagree }\end{array} & & & & & & \text { Totally } \\ \text { Agree }\end{array}$

23. I study a course material by skipping over parts I think the teacher will not ask questions about.

$\begin{array}{ccccccc}1 & 2 & 3 & 4 & 5 & 6 & 7 \\ \begin{array}{c}\text { Totally } \\ \text { Disagree }\end{array} & & & & & & \text { Totally } \\ \text { Agree }\end{array}$

24. I study a course material by summarizing it.

$\begin{array}{ccccccc}1 & 2 & 3 & 4 & 5 & 6 & 7 \\ \begin{array}{c}\text { Totally } \\ \text { Disagree }\end{array} & & & & & & \text { Totally } \\ \text { Agree }\end{array}$

25. I study a course material by combining different sources (book, notes, ....).

$\begin{array}{ccccccc}1 & 2 & 3 & 4 & 5 & 6 & 7 \\ \text { Totally } & & & & & & \text { Totally } \\ \text { Disagree } & & & & & & \end{array}$

26. I study a course material by memorizing something I do not understand.

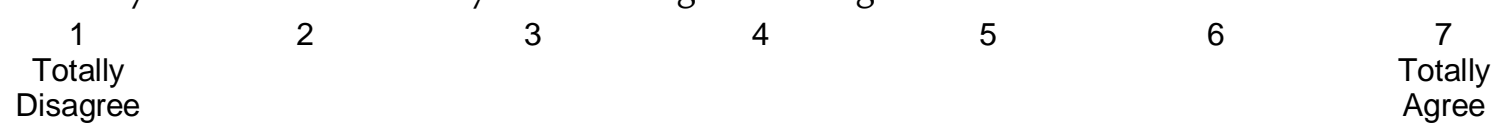

27. I study a course material by repeating the material until I can say it exactly like what appears in that material.

$\begin{array}{ccccccc}1 & 2 & 3 & 4 & 5 & 6 & 7 \\ \begin{array}{c}\text { Totally } \\ \text { Disagree }\end{array} & & & & & & \text { Totally } \\ \text { Agree }\end{array}$


28. I study a course material by connecting course material from different courses.

$\begin{array}{ccccccc}1 & 2 & 3 & 5 & 6 & 7 \\ \text { Totally } & & & & & \text { Totally } \\ \text { Disagree } & & & & & \text { Agree }\end{array}$

29. I study a course material by distinguishing main points and details.

$\begin{array}{ccccccc}1 & 2 & 3 & 4 & 5 & 6 & 7 \\ \text { Totally } & & & & & \text { Totally } \\ \text { Disagree } & & & & & \text { Agree }\end{array}$

30. I study a course material by studying something that is not clear again in order to understand it.

$\begin{array}{ccccccc}1 & 2 & 3 & 5 & 6 & 7 \\ \text { Totally } & & & & & \text { Totally } \\ \text { Disagree } & & & & \text { Agree }\end{array}$

31. I study a course material by skipping parts I do not understand.

$\begin{array}{ccccccc}1 & 2 & 3 & 4 & 5 & 6 & 7 \\ \text { Totally } & & & & \text { Totally } \\ \text { Disagree } & & & & \text { Agree }\end{array}$

32. I study a course material by underlining the most important parts.

$\begin{array}{ccccccc}1 & 2 & 3 & 4 & 6 & 7 \\ \text { Totally } & & & & & \text { Totally } \\ \text { Disagree } & & & & \text { Agree }\end{array}$

33. I study a course material by skipping parts I do not find important.

$\begin{array}{ccccccc}1 & 2 & 3 & 4 & 6 & 7 \\ \text { Totally } & & & & & \text { Totally } \\ \text { Disagree } & & & & \text { Agree }\end{array}$

\section{Background Information}

34. Please indicate your gender.
1. Male
2. Female

35. Please indicate your learning shift.
1. Morning
2. Afternoon
3. Evening

This is the end of the questionnaire.

Thank you for your participation. 


\section{Appendix B \\ Principal-Component Factor Analyses on Writing Self-Efficacy and Writing Goal Orientation Scales and the Correlation Matrix Among the Variables}

\section{Table B1}

Factor Loadings from Principal-Component Factor Analysis of the Writing Self-Efficacy Items

Items

5. put ideas together in a paragraph in such a way that they are clear to the reader

6. link sentences together to make a well-organized paragraph

4. write a good introduction which informs the reader of my intention for a paragraph

3. plan my paragraph well

1. write a grammatically correct paragraph

7. make a good conclusion to inform the reader the ending of my paragraph

2. use correct punctuation marks-for example commas, full stops, semi-colons, etc.-in a paragraph

\section{Table B2}

Factor Loadings from Principal-Component Factor Analysis of Writing Goal Orientation Items

Item: When I do a writing assignment, writing in-class work, or writing homework,

\begin{tabular}{ccc}
\multicolumn{3}{c}{ Factor Loadings } \\
\hline PAPG & PAVG MG
\end{tabular}

14. one of my goals is to look smart compared to others in my class.

.89

13. it's important for me to look smart in comparison to the other students in my class.

16. it's important to me that other students in my class think I am good at it.

18. it's important to me that others don't see me as a stupid student.

19. it's important to me that my teachers don't think that I know less than others in class.

21. one of my goals is to avoid looking like I have trouble doing the work.

20. one of my goals is to keep others from thinking I'm not smart.

8. it's important to me that I learn as much as I can.

9. it's important to me that I improve my skills and knowledge.

10. one of my goals is to learn as much as I can.

12. one of my goals is to develop deep understanding of what I am learning.

11. it's important for me to really understand what there is to learn.

Note. PAPG = writing performance-approach goal orientation, PAVG = writing performance-avoidance goal orientation, $\mathrm{MG}=$ writing mastery goal orientation. Only loadings higher than .40 on only one component are presented.

\section{Table B3}

Matrix of Correlation Among Dependent Variable, Predictor Variables, and Background Variables

\begin{tabular}{llllll}
\hline & Ach & Pr_Ach & SE & MG & PAPG \\
\hline Pr_Ach & $.435^{\star * *}$ & & & & \\
SE & $.149^{*}$ & $.145^{*}$ & & & \\
MG & $.112^{*}$ & .017 & $.404^{* \star *}$ & & \\
PAPG & -.045 & -.025 & .035 & $.143^{*}$ & \\
PAVG & -.021 & -.079 & $.168^{\star *}$ & $.137^{*}$ & $.390^{\star * *}$ \\
\hline
\end{tabular}

Note. Ach = writing achievement, Pr_Ach = previous writing achievement, SE = writing self-efficacy, MG = writing mastery goal orientation, PAPG = writing performance-approach goal orientation, PAVG = writing performanceavoidance goal orientation; ${ }^{* *} p<.001,{ }^{* *} p<.01,{ }^{*} p<.05$. 